\title{
WAGE PUNISHMENT AND PLACE OF RESIDENCE*
}

\author{
Adolfo Sachsida ${ }^{\S}$ \\ Mario Jorge Cardoso de Mendonça ${ }^{\not}$ \\ Paulo Roberto Amorim Loureiro ${ }^{\dagger}$
}

\begin{abstract}
RESUMO
Este artigo testa a hipótese de punição salarial contra moradores de regiões pobres. Isto é, nós explicitamente testamos a idéia de que trabalhadores morando em regiões pobres recebem uma punição salarial em relação a trabalhadores similares que moram em regiões ricas. Os resultados econométricos são robustos tanto a um amplo conjunto de variáveis explicativas como também a diferentes especificações econométricas. Estimadores de 2 e 3 estágios são usados para corrigir tanto o viés de endogeneidade, associado ao local de moradia, como também para a correção do viés associado a ausência de uma proxy adequada para a variável habilidade. Os resultados econométricos sugerem expressiva punição salarial para os moradores de regiões pobres. Além disso, quatro explicações para a correlação entre salários e local de moradia foram testadas. Os resultados fornecem evidências favoráveis a: i) existência de uma relação negativa entre o tempo gasto para se chegar de casa ao trabalho e a produtividade do trabalhador; e b) ocorrência de discriminação estatística contra trabalhadores que residem em regiões pobres.
\end{abstract}

Palavras-chave: punição salarial, discriminação espacial, local de residência.

\begin{abstract}
This article tests the hypothesis of wage punishment against workers living in poor counties. That is, we explicitly test the idea that workers living in poor counts receive a wage punishment in relation to similar skilled workers living in rich counties. The econometric results are robust to both a large set of explanatory variables and different econometric specifications. The 2 Stages and the 3 Stages Least Squares approach are used to correct both the endogeneity of the place of residence and the omission of the variable ability (ability bias). After all, the results suggest expressive wage punishment against workers that lived in poor areas. Furthermore, four alternative explanations for the correlation between wages and place of residence are tested and the results provide evidence in favor of i) a link between time spent commuting to workplace and productivity of the worker; and ii) statistical discrimination against workers that live in poor areas.
\end{abstract}

Keywords: wage punishment, spatial discrimination, place of residence.

JEL classification: J71, J31.

* Os autores agradecem aos participantes do XXIX Encontro Brasileiro de Econometria, bem como a dois pareceristas anônimos, por comentários e sugestões que em muito contribuíram para a qualidade deste trabalho. Eventuais erros e/ou omissões permanecem de inteira responsabilidade dos autores.

$\S$ Catholic University of Brasília and IPEA. Address to correspondence: Catholic University of Brasília, SGAN 916, Modulo B, Sala A-118, 70790-160 Brasília, DF.E-mail: sachsida@pos.ucb.br.

a Institute of Applied Economic Research. E-mail: mjorge@hotmail.com.

$\dagger \quad$ Catholic University of Brasília. E-mail: loureiro77@hotmail.com.

Recebido em novembro de 2007. Aceito para publicação em junho de 2008. 


\section{INTRODUCTION}

Studies that relate wage differences to the existence of discrimination in the labor market are common in economics [Becker (1957), Phelps (1972), inter alia]. However, recent studies have expanded such literature to include important topics in such discussions. These works seem to show that the discrimination phenomenon is not limited to solely the race or sex of the individual, but can also expand to include people of the same race and sex. Physical appearance [Hamermesh and Biddle (1994)], physically handicaps [Famulari (1992)], height [Persico and Postlewaite (2004)] or even the place of residence [Kain (1968)] have become new variables that may incite some kind of wage discrimination against an individual.

Wage or job opportunity punishment may occur for several reasons. One reason is that statistical discrimination may occur. For example, if an individual lives in a neighborhood known to house a certain type of people (poor people, for example), the employer may associate the characteristics of people from that area to the individual in question, thus reducing his chances of being contracted, or earning a higher wage. Secondly, discrimination by preference could take place. This means that the employer simply does not like people that live in certain neighborhoods (or cities). Thirdly, a person may have poor job opportunities if the Spatial Mismatch Hypothesis (SMH) exists which states that individuals who live far from their workplaces have difficulty accessing the best job opportunities [Kain (1968)]. ${ }^{1}$ Lastly, there is some economic rationality to the fact that wages are related to the dwelling place of the individual. For example, people who live far from their workplaces might spend more time and energy in traffic, thus reducing their capacity to produce once in the job.

The objective of this article is to verify the effect of the place of residence over an individual's wage. Furthermore, the different explanations that can cause this result are tested. It is important to stress that to complete this study the construction of a new data set was necessary. The econometric results indicate severe wage punishment against workers living in poor counties. More than that, the econometric evidence suggests that both the statistical discrimination and the economic rationale explanation cannot be ruled out. Besides this introduction, section 2 presents a detailed description of the dataset. Section 3 presents the econometric results. Lastly, section 4 describes the conclusions of the article.

\section{DATASET}

The dataset refers to the Distrito Federal State, which lies in the central count of Brazil. According to the 2000 census data from the Brazilian Institute of Geography and Statistics, the population of the Distrito Federal was 2,051,146 inhabitants who are spread throughout 19 administrative counts. Due to budget limitations, this research was limited to 4 of these coun-

1 For a more detailed review of SMH, see Gobillon, Selod and Zenou (2003), Boardman and Field (2002), Gabriel and Rosenthal (1996) and Kain (1992). 
ties: Brasília (population: 198,422), Taguatinga (population: 243,575), Sobradinho (population 128,789) and Ceilândia (population 344,039). As a group, these 4 counties equal $44.6 \%$ of the population of the Distrito Federal State.

Table 1 shows the distribution of the population of the Distrito Federal States in its different administrative counties in 2000. They are listed according to population size. Also shown is the Index of Human Development (IDH), the average annual income per capita and per family, and the average family size.

Table 1 - Administrative counts of the Distrito Federal State*

\begin{tabular}{lcccccc}
\hline Administrative Count & Population & $\%$ & IDH & $\begin{array}{c}\text { Average Annual } \\
\text { Income per capita }\end{array}$ & $\begin{array}{c}\text { Average Size of } \\
\text { Families }\end{array}$ & $\begin{array}{c}\text { Average Annual } \\
\text { Income per family }\end{array}$ \\
\hline Ceilândia & 344,039 & 16.8 & .784 & 2,217 & 4.32 & 9,575 \\
Taguatinga & 243,575 & 11.9 & .853 & 4,818 & 4.20 & 20,236 \\
Brasília & 198,422 & 9.7 & .936 & 10,890 & 3.75 & 40,837 \\
Samambaia & 164,319 & 8.0 & .781 & 2,251 & 4.27 & 9,613 \\
Planaltina & 147,114 & 7.2 & .764 & 1,832 & 4.20 & 7,696 \\
Gama & 130,580 & 6.4 & .815 & 2,756 & 4.13 & 11,382 \\
Sobradinho & 128,789 & 6.3 & .837 & 3,395 & 4.10 & 13,918 \\
Guará & 115,385 & 5.6 & .867 & 6,404 & 4.07 & 26,063 \\
Santa Maria & 98,679 & 4.8 & .794 & 1,373 & 4.57 & 6,277 \\
Rec. Das Emas & 93,287 & 4.5 & .775 & 1,392 & 4.29 & 5,971 \\
São Sebastião & 64,322 & 3.1 & .820 & 1,610 & 4.14 & 6,667 \\
Cruzeiro & 63,883 & 3.1 & .928 & 7,529 & 4.02 & 30,266 \\
Paranoá & 54,902 & 2.7 & .785 & 1,343 & 4.31 & 5,788 \\
Brazlândia & 52,698 & 2.6 & .761 & 1,904 & 4.30 & 8,187 \\
Riacho Fundo & 41,404 & 2.0 & .826 & 2,808 & 4.40 & 12,353 \\
N. Bandeirante & 36,472 & 1.8 & .898 & 5,852 & 3.90 & 22,823 \\
Lago Norte & 29,505 & 1.4 & .933 & 15,910 & 4.17 & 66,344 \\
Lago Sul & 28,137 & 1.4 & .945 & 21,389 & 3.87 & 82,777 \\
Candangolândia & 15,634 & 0.8 & .853 & 3,387 & 4.23 & 14,325 \\
\hline Distrito Federal & $2,051,146$ & 100 & .849 & 4,518 & 4.15 & 18,750 \\
\hline & & & & & & \\
\hline
\end{tabular}

* the population data comes from the census data elaborated by the Brazilian Institute of Geography and Statistics in the year of 2000. The data about income (in 1997 US\$ values), the size of family and IDH come from the Distrito Federal Company to Development (CODEPLAN).

The reason we chose Brasília, Taguatinga, Ceilândia and Sobradinho as targets for this study is due to 4 reasons; a) in political terms, Brasília (the capital of Brazil) is the principal count of the Distrito Federal State. In it we find the National Congress, the Planalto Palace 
(home of the President of the Republic), the ministries, etc.; b) Taguatinga and Ceilândia are the most populous and important areas in the south of Brasília (an average distance of 20 miles from the center of Brasília); c) Sobradinho is the most populous and important administrative county north of Brasília (around 17 miles from the center of Brasília); and d) these four populous areas have existed long enough to have their own dynamics. ${ }^{2}$

Data collection took place during May and June of 2004, in the administrative counties of Brasília, Taguatinga, Ceilândia and Sobradinho. A total of 1,104 people were interviewed. They answered a sixty-question questionnaire regarding socio-economical and behavioral characteristics. To obtain a more homogenous sampling, only people between the ages of 25 and 55 years old were interviewed. Moreover, all the individuals who called themselves public employees (civil or military) were not interviewed due to the fact that the dynamics that ruled their wages was different from that of the market. The average time to complete the form was approximately 7 minutes. The individuals were interviewed in different points in the administrative counties. In addition, the interviewers participated in 8 hours of instruction concerning how to conduct good interviews.

Not all the information collected was used in this article. Furthermore, as is usual in econometric studies, some filters were applied to the sample. Following the standard procedure of literature regarding the return to schooling, individuals who were still studying were excluded also. For the same reason people with an hourly wage of more than $\mathrm{R} \$ 300$ (approximately US $\$$ 100 ) or less than $\mathrm{R} \$ 1.00$ were also withdrawn from the sampling. Finally, only individuals with a weekly workload of 36 to 44 hours were included in the sample. As a result of these filters the sampling size was reduced to 799 individuals.

Table 2 presents some descriptive statistics concerning the sample used for this research. The results are separated by administrative counts. For example, an individual who lives in Brasília studies approximately 15.87 years. However, for a resident of Sobradinho, this same measurement is reduced to 9.60. In addition, the number of years of study in private schools is greater for people who live in Brasília than for those who live in other counts. Also, in reference to Table 2 , it is noted that $52 \%$ of those interviewed who live in Brasília speak a second language, in contrast to $22 \%$ of those who live in Taguatinga, $4 \%$ of those residing in Ceilândia and $16 \%$ of those in Sobradinho. Another interesting detail is that while $87 \%$ of Brasília residents own their own car, this percentage decreases to $39 \%$ in Ceilândia and $34 \%$ in Sobradinho.

2 Ceilândia, which is the youngest administrative region of the four mentioned, was founded March, 1971. 
Table 2 - Descriptive statistics*

\begin{tabular}{|c|c|c|c|c|}
\hline Variable & Brasília & Taguatinga & Ceilândia & Sobradinho \\
\hline Years of schooling (S) & $15.87(2.88)$ & $\begin{array}{l}11.94 \\
(3.26)\end{array}$ & $\begin{array}{c}9.81 \\
(2.92)\end{array}$ & $\begin{array}{c}9.60 \\
(4.25)\end{array}$ \\
\hline Years of schooling in private schools (Spriv) & $6.22(5.83)$ & $\begin{array}{c}3.09 \\
(4.91)\end{array}$ & $\begin{array}{l}0.29 \\
(.84)\end{array}$ & $\begin{array}{c}1.55 \\
(3.28)\end{array}$ \\
\hline Years of schooling of his/her mother (Smother) & $\begin{array}{c}9.84 \\
(4.87)\end{array}$ & $\begin{array}{c}7.78 \\
(4.32)\end{array}$ & $\begin{array}{c}4.96 \\
(3.43)\end{array}$ & $\begin{array}{c}4.86 \\
(4.26)\end{array}$ \\
\hline Speak another Language (Lang) & $\begin{array}{l}0.52 \\
(.50)\end{array}$ & $\begin{array}{l}0.22 \\
(.42)\end{array}$ & $\begin{array}{l}0.04 \\
(.21)\end{array}$ & $\begin{array}{l}0.16 \\
(.37)\end{array}$ \\
\hline Know Excel/Word (exword) & $\begin{array}{l}0.96 \\
(.19)\end{array}$ & $\begin{array}{l}0.70 \\
(.45)\end{array}$ & $\begin{array}{l}0.47 \\
(.50)\end{array}$ & $\begin{array}{l}0.47 \\
(.50)\end{array}$ \\
\hline Have ever been promoted in the job (prom) & $\begin{array}{l}0.67 \\
(.46)\end{array}$ & $\begin{array}{l}0.38 \\
(.48)\end{array}$ & $\begin{array}{l}0.29 \\
(.45)\end{array}$ & $\begin{array}{l}0.28 \\
(.45)\end{array}$ \\
\hline Union membership (union) & $\begin{array}{l}0.47 \\
(.50)\end{array}$ & $\begin{array}{l}0.48 \\
(.50)\end{array}$ & $\begin{array}{l}0.70 \\
(.45)\end{array}$ & $\begin{array}{l}0.19 \\
(.39)\end{array}$ \\
\hline Work in the formal sector (formal) & $\begin{array}{l}0.96 \\
(.19)\end{array}$ & $\begin{array}{l}0.82 \\
(.37)\end{array}$ & $\begin{array}{l}0.87 \\
(.33)\end{array}$ & $\begin{array}{l}0.86 \\
(.33)\end{array}$ \\
\hline $\operatorname{man}(\operatorname{man})$ & $\begin{array}{l}0.62 \\
(.48)\end{array}$ & $\begin{array}{l}0.50 \\
(.50)\end{array}$ & $\begin{array}{l}0.71 \\
(.45)\end{array}$ & $\begin{array}{l}0.64 \\
(.47)\end{array}$ \\
\hline white (white) & $\begin{array}{l}0.73 \\
(.44)\end{array}$ & $\begin{array}{l}0.72 \\
(.44)\end{array}$ & $\begin{array}{l}0.32 \\
(.46)\end{array}$ & $\begin{array}{l}0.65 \\
(.47)\end{array}$ \\
\hline married (married) & $\begin{array}{l}0.49 \\
(.50)\end{array}$ & $\begin{array}{l}0.44 \\
(.49)\end{array}$ & $\begin{array}{l}0.58 \\
(.49)\end{array}$ & $\begin{array}{l}0.54 \\
(.49)\end{array}$ \\
\hline Has children (child) & $\begin{array}{l}0.56 \\
(.49)\end{array}$ & $\begin{array}{l}0.44 \\
(.49)\end{array}$ & $\begin{array}{l}0.70 \\
(.45)\end{array}$ & $\begin{array}{l}0.57 \\
(.49)\end{array}$ \\
\hline Owns house (house) & $\begin{array}{l}0.54 \\
(.49)\end{array}$ & $\begin{array}{l}0.45 \\
(.49)\end{array}$ & $\begin{array}{l}0.41 \\
(.49)\end{array}$ & $\begin{array}{l}0.49 \\
(.50)\end{array}$ \\
\hline Owns car (car) & $\begin{array}{l}0.87 \\
(.33)\end{array}$ & $\begin{array}{l}0.47 \\
(.50)\end{array}$ & $\begin{array}{l}0.39 \\
(.49)\end{array}$ & $\begin{array}{l}0.34 \\
(.47)\end{array}$ \\
\hline Hours worked per week (hours) & $\begin{array}{l}40.35 \\
(1.16)\end{array}$ & $\begin{array}{c}40.26 \\
(2.05)\end{array}$ & $\begin{array}{l}40.77 \\
(2.13)\end{array}$ & $\begin{array}{l}41.19 \\
(1.93)\end{array}$ \\
\hline Monthly wage (w) & $\begin{array}{c}3,585.79 \\
(1,951)\end{array}$ & $\begin{array}{c}1,316.63 \\
(1,383)\end{array}$ & $\begin{array}{c}740.97 \\
(521.74)\end{array}$ & $\begin{array}{l}955.38 \\
(1,184)\end{array}$ \\
\hline $\begin{array}{l}\text { Monthly wage divided by number of hours } \\
\text { worked per week (wh) }\end{array}$ & $\begin{array}{c}89.27 \\
(49.05)\end{array}$ & $\begin{array}{c}32.79 \\
(34.47)\end{array}$ & $\begin{array}{c}18.24 \\
(13.00)\end{array}$ & $\begin{array}{c}23.55 \\
(29.61)\end{array}$ \\
\hline Number of observations & 185 & 188 & 186 & 220 \\
\hline
\end{tabular}

* the values in parentheses are the standard deviations of the variables.

\section{ECONOMETRIC RESULTS}

The primary objective in this section is to verify the effect of the place of residence over an individual wage by estimating the mincerian equation of wages as a function of a set of exo- 
genous variables that measures both human capital and individual characteristics. Mincerian equations are common throughout studies that concern return to schooling [Mincer (1974), Griliches (1977), Garen (1984), Card (2001), inter alia]. Two problems associated with the use of mincerian equations in wage estimates are: a) the ability bias (that is, the ability of an individual is not easily measured - its absence in the model may cause an estimative bias); and b) the endogeneity of the schooling variable. In the construction of the dataset, special attention was give to both these problems. Thus, in the questionnaire, questions were included that captured the "ability" of an individual (if he spoke another language, if he knew how to work with software like Word and Excel, how many years he had studied in private school, how many years his mother had studied and if he had ever been promoted in the job). On the other hand, in an attempt to solve the problem of endogeneity of the education variable, a two-stage least square model was estimated. Later in this text more detail will be provided in regard to these proceedings.

It is important to emphasize that the authors of this article are not concerned about the return to education. ${ }^{3}$ The authors utilize a mincerian framework to verify the importance of the place of residence on individual wages. In this sense, the problems of the omission of the variable ability and the endogeneity issue must be understood within the scope of this paper. That is, the problem of such "ability bias" lies in the fact that individuals with high amount of ability can receive higher wages and live in richer counties. If this is true, the fact of residence location affecting wages will be a spurious fact, because the true effect will be generated by the ability variable, which was omitted in the equation. In a similar manner, the choice of the place of residence may be endogenous. For example, the individual can choose the place of residence according to his wage, or can even choose to live close to his/her job.

Table 3 shows the results obtained by ordinary least squares (OLS) as well as Two-Stage least squares (2-LS). In this table, the dependent variable is the logarithm of the monthly wage per hour worked during the week (Lwh). Two groups of explanatory variables have been adopted. In the first group the classic set of variables that appear in the studies on returns to education is utilized. The second group adds the following variables to the previous set: an individual's ability to speak another language (lang), if the applicant knows how to work with software like Word and Excel (exword), how many years the person studied in private school (Spriv), the number of years of education of the applicant's mother (Smother), whether or not the individual has ever been promoted (prom), and if he owned his own house (house). The premise is that this new set of variables can possibly isolate the effect of the ability variable, eliminating (or reducing) the ability bias. A dummy variable was also included which became a value equal to 1 (one) if the individual has children and 0 (zero) if not. The justification for the inclusion of this variable is to try to capture the effect of the presence of children on the individual's wage. To verify the effect of mobility on the individual's wage, a dummy variable (car) that assumed the value 1 (one) if the individual owned a car was also included in the regression. Finally, in each estimate a count dummy was included which assumed the value

3 Sachsida, Loureiro and Mendonça (2004), Resende and Wyllie (2006), Barbosa Filho and Pessôa (2008), and Moura (2008), present estimates of returns to education for the Brazilian economy. 
1 (one) if the person lived in that count and 0 (zero) if not. Brasília was considered the base county.

Table 3 shows some interesting results on wages, such as the effect of schooling and particularly, private schooling. However, we will focus on the effect of residence location on individual wages. Even using the wide set of variables (equations 2 and 4), there is strong evidence of the occurrence of wage discrimination due to the place of residence of the individual. Using the full set of variables to capture the idea of ability, the OLS estimation indicates a wage punishment of 38 percent for the individuals that live in Taguatinga, 52 percent for the inhabitants of Ceilândia and 58 percent for the inhabitants of Sobradinho. To address the endogeneity problem in the choice of the location to live, the wage equation is re-estimated by two-stages least squares (the place of residence is the endogenous variable and we use the following set of exogenous variables: smother, race, smoke, drink, kids, and wage). The 2-LS regression shows no wage penalty against the inhabitants of Taguatinga, but strong wage punishment for the inhabitants of both Ceilândia and Sobradinho.

The results in Table 3 imply an elevated wage punishment for those living in Ceilândia and Sobradinho, in relation to the residents of Brasília. In an attempt to corroborate this result and show its robustness, a proxy is used for the place of residence. Why is this procedure necessary? Because one may argue that the instruments used to instrumentalize the place of residence were not appropriate. If a bad set of instruments were used, the problem of endogeneity for the place of residence would remain. To eliminate this problem a variable is used that is highly correlated to the present place of residence, but does not have a relation to the error term in the wage equation. If such a variable is found, it can be used as a proxy for the place of residence, without being subject to the criticism regarding endogeneity. 
Table 3 - Preliminary estimative on the relation between place of residence and wages*

\begin{tabular}{|c|c|c|c|c|}
\hline \multirow[t]{2}{*}{ Dependent Variable: Lwh } & \multicolumn{2}{|c|}{ OLS } & \multicolumn{2}{|c|}{$2-L^{* *}$} \\
\hline & (1) & (2) & (3) & (4) \\
\hline$S$ & $\begin{array}{c}.1446 \\
(21.99)\end{array}$ & $\begin{array}{c}.0881 \\
(12.56)\end{array}$ & $\begin{array}{l}.0511 \\
(3.63)\end{array}$ & $\begin{array}{l}.0291 \\
(1.92)\end{array}$ \\
\hline Experience & $\begin{array}{l}.0410 \\
(4.99)\end{array}$ & $\begin{array}{l}.0453 \\
(6.01)\end{array}$ & $\begin{array}{l}.0708 \\
(4.29)\end{array}$ & $\begin{array}{l}.0637 \\
(3.99)\end{array}$ \\
\hline Experience ${ }^{\wedge} 2$ & $\begin{array}{l}-.0004 \\
(-2.66)\end{array}$ & $\begin{array}{l}-.0006 \\
(-3.90)\end{array}$ & $\begin{array}{c}-.0011 \\
(-3.33)\end{array}$ & $\begin{array}{c}-.0011 \\
(-3.34)\end{array}$ \\
\hline Formal & $\begin{array}{l}.0971 \\
(1.50)\end{array}$ & $\begin{array}{l}.0725 \\
(1.27)\end{array}$ & $\begin{array}{l}.2772 \\
(2.14)\end{array}$ & $\begin{array}{l}.2866 \\
(2.17)\end{array}$ \\
\hline Union & $\begin{array}{l}.0091 \\
(0.20)\end{array}$ & $\begin{array}{c}-.0293 \\
(-0.73)\end{array}$ & $\begin{array}{c}-1879 \\
(-1.60)\end{array}$ & $\begin{array}{c}-.3107 \\
(-2.58)\end{array}$ \\
\hline Man & $\begin{array}{l}.1934 \\
(4.68)\end{array}$ & $\begin{array}{l}.1261 \\
(3.45)\end{array}$ & $\begin{array}{l}.2936 \\
(3.58)\end{array}$ & $\begin{array}{l}.2499 \\
(3.03)\end{array}$ \\
\hline White & $\begin{array}{l}.0647 \\
(1.52)\end{array}$ & $\begin{array}{c}-.0128 \\
(-0.34)\end{array}$ & $\begin{array}{c}-.1466 \\
(-1.37)\end{array}$ & $\begin{array}{c}-.1586 \\
(-1.48)\end{array}$ \\
\hline Married & $\begin{array}{l}.2135 \\
(4.95)\end{array}$ & $\begin{array}{l}.1469 \\
(3.48)\end{array}$ & $\begin{array}{l}.3035 \\
(4.17)\end{array}$ & $\begin{array}{l}.1876 \\
(2.24)\end{array}$ \\
\hline Spriv & & $\begin{array}{l}.0221 \\
(4.77)\end{array}$ & & $\begin{array}{c}.0022 \\
(0.23)\end{array}$ \\
\hline Smother & & $\begin{array}{l}.0023 \\
(0.51)\end{array}$ & & $\begin{array}{c}-.0281 \\
(-2.85)\end{array}$ \\
\hline Lang & & $\begin{array}{l}.1843 \\
(3.77)\end{array}$ & & $\begin{array}{l}.2480 \\
(2.42)\end{array}$ \\
\hline Exword & & $\begin{array}{l}.0851 \\
(1.74)\end{array}$ & & $\begin{array}{c}-.0264 \\
(-0.27)\end{array}$ \\
\hline Prom & & $\begin{array}{l}.3007 \\
(7.55)\end{array}$ & & $\begin{array}{l}.2325 \\
(3.01)\end{array}$ \\
\hline Child & & $\begin{array}{c}-.0172 \\
(-0.38)\end{array}$ & & $\begin{array}{l}.0437 \\
(0.46)\end{array}$ \\
\hline House & & $\begin{array}{l}.0691 \\
(1.83)\end{array}$ & & $\begin{array}{l}.2565 \\
(3.37)\end{array}$ \\
\hline Car & & $\begin{array}{l}.3685 \\
(8.60)\end{array}$ & & $\begin{array}{l}.2183 \\
(2.53)\end{array}$ \\
\hline Taguatinga & $\begin{array}{c}-.5378 \\
(-8.65)\end{array}$ & $\begin{array}{c}-3827 \\
(-6.85)\end{array}$ & $\begin{array}{c}-.6484 \\
(-1.75)\end{array}$ & $\begin{array}{c}-.3247 \\
(-0.85)\end{array}$ \\
\hline Ceilândia & $\begin{array}{c}-.7506 \\
(-10.48)\end{array}$ & $\begin{array}{c}-.5281 \\
(-8.06)\end{array}$ & $\begin{array}{c}-2.109 \\
(-8.16)\end{array}$ & $\begin{array}{c}-1.818 \\
(-6.27)\end{array}$ \\
\hline Sobradinho & $\begin{array}{c}-.7665 \\
(-11.69)\end{array}$ & $\begin{array}{c}-.5864 \\
(-9.78)\end{array}$ & $\begin{array}{c}-2.741 \\
(-11.58)\end{array}$ & $\begin{array}{c}-2.674 \\
(-10.14)\end{array}$ \\
\hline Constant & $\begin{array}{l}1.178 \\
(7.93)\end{array}$ & $\begin{array}{c}1.334 \\
(9.82)\end{array}$ & $\begin{array}{c}2.889 \\
(8.16)\end{array}$ & $\begin{array}{c}3.018 \\
(8.12)\end{array}$ \\
\hline $\mathrm{R}^{2}$ Adj. & .6847 & .7613 & .1242 & .1115 \\
\hline Number of observations & 779 & 778 & 778 & 777 \\
\hline
\end{tabular}

* the values in parentheses are the $t$ tests of the variables. ** : the instrumentalized variables were Taguatinga, Ceilândia and Sobradinho, and the instruments used were: Lwh, and dummies that indicated if the individual had friends in the count, relatives in the count, if he worked in the count, if he/she would like to move to other administrative count, where he/she lived five years ago and if he/she were afraid of violence. 
In the questionnaire there is the following question: "In what administrative county did you live 5 years ago?" One would not expect that the count a person lived in 5 years ago would bear influence on the error term of the wage equation. Nevertheless, if there is a high correlation between where an individual lived 5 years ago and where he presently lives, this variable can be used as a proxy for the place of residence. Table 4 describes a distribution of individuals by current place of residence and that of 5 years ago. An important detail is that, 5 years ago, some people lived in a county outside the counties studied here. Such people were grouped in the group "other counties". Column 1 describes the distribution of the place of residence 5 years ago. Column 2 describes the same variable, without taking into account the "other counties" group. Column 3 describes the current distribution. Finally, the last line of Table 4 describes the correlation between the place of residence 5 years ago and the present dwelling place. As indicated by this table, there is a significant correlation between the locations of past and present residences. For example, in the case where "other counties" is not included the correlation is 0.74 .

Table 4 - Distribution of individuals according to their past and present place of residence

\begin{tabular}{lccc}
\hline Administrative Count & 5 years ago & 5 years ago without including "other counts" & Atual \\
\hline Brasilia & $17.85 \%$ & $21.32 \%$ & $23.75 \%$ \\
Taguatinga & $19.38 \%$ & $23.16 \%$ & $24.13 \%$ \\
Ceilândia & $21.18 \%$ & $25.31 \%$ & $23.88 \%$ \\
Sobradinho & $25.29 \%$ & $30.21 \%$ & $28.24 \%$ \\
Other counts & $16.30 \%$ & - & - \\
\hline Correlation with the actual count & 0.4723 & 0.7439 & - \\
\hline
\end{tabular}

Table 5 shows the result of the wage estimate ( $\mathrm{Lwh}$ ), by ordinary least squares, using the individual's place of residence 5 years ago as a proxy for the present living place. As mentioned above, it is expected that this procedure reduces, or eliminates, the criticism of endogeneity of the place of residence in the wage equation. Once again, residents outside the administrative county of Brasília are subjected to heavy wage punishment. Note that in Table 5 the base county refers to individuals who lived in Brasília 5 years ago. The results of Table 5 can be interpreted the following way: individuals who lived in Taguatinga 5 years ago actually receive a wage between 23 and 39 percent less than those individuals who lived in Brasília 5 years ago. Since the place of residence 5 years ago is being used as proxy to represent the present place of residence, the residents of Taguatinga receive a wage punishment between 23 and 39 percent in relation to the residents of Brasília. In a similar way, the residents of Ceilândia receive between 27 and 53 percent less than the residents of Brasília. For the Sobradinho county, this wage punishment varies, depending on the estimate, between 35 and 55 percent. We would also like to stress that the residents of "other counties" also receive a wage punishment that, depending on the estimate, can be as high as 32 percent. These remaining results are similar to those described in Table 3. 
Table 5 - Estimate on the relation between place of residence 5 years ago and wages*

\begin{tabular}{|c|c|c|c|c|}
\hline \multirow[t]{2}{*}{ Variável Dependente: Lwh } & \multicolumn{2}{|c|}{ Without "Other Counts" } & \multicolumn{2}{|c|}{ With "Other Counts" } \\
\hline & (1) & (2) & (3) & (4) \\
\hline S & $\begin{array}{c}.1616 \\
(23.34)\end{array}$ & $\begin{array}{c}.0994 \\
(13.03)\end{array}$ & $\begin{array}{c}.1700 \\
(26.86)\end{array}$ & $\begin{array}{c}.1029 \\
(14.58)\end{array}$ \\
\hline Experience & $\begin{array}{l}.0430 \\
(4.67)\end{array}$ & $\begin{array}{l}.0495 \\
(5.83)\end{array}$ & $\begin{array}{l}.0380 \\
(4.40)\end{array}$ & $\begin{array}{l}.0453 \\
(5.78)\end{array}$ \\
\hline Experience ${ }^{\wedge}$ & $\begin{array}{c}-.0004 \\
(-2.38)\end{array}$ & $\begin{array}{l}-.0006 \\
(-3.68)\end{array}$ & $\begin{array}{c}-.0003 \\
(-1.86)\end{array}$ & $\begin{array}{c}-.0005 \\
(-3.36)\end{array}$ \\
\hline Formal & $\begin{array}{l}.1524 \\
(2.12)\end{array}$ & $\begin{array}{l}.1079 \\
(1.71)\end{array}$ & $\begin{array}{l}.1175 \\
(1.72)\end{array}$ & $\begin{array}{l}.0828 \\
(1.40)\end{array}$ \\
\hline Union & $\begin{array}{l}.0029 \\
(0.06)\end{array}$ & $\begin{array}{l}-.0331 \\
(-0.75)\end{array}$ & $\begin{array}{c}-.0193 \\
(-0.42)\end{array}$ & $\begin{array}{c}-.0442 \\
(-1.11)\end{array}$ \\
\hline Man & $\begin{array}{l}.1448 \\
(3.08)\end{array}$ & $\begin{array}{l}.0923 \\
(2.23)\end{array}$ & $\begin{array}{l}.2086 \\
(4.78)\end{array}$ & $\begin{array}{c}.1266 \\
(3.32)\end{array}$ \\
\hline White & $\begin{array}{l}.0820 \\
(1.71)\end{array}$ & $\begin{array}{l}.0032 \\
(0.08)\end{array}$ & $\begin{array}{l}.1166 \\
(2.65)\end{array}$ & $\begin{array}{l}.0188 \\
(0.49)\end{array}$ \\
\hline Married & $\begin{array}{l}.1902 \\
(3.86)\end{array}$ & $\begin{array}{l}.1453 \\
(3.01)\end{array}$ & $\begin{array}{l}.1958 \\
(4.30)\end{array}$ & $\begin{array}{c}.1372 \\
(3.11)\end{array}$ \\
\hline Spriv & & $\begin{array}{l}.0232 \\
(4.38)\end{array}$ & & $\begin{array}{l}.0248 \\
(5.12)\end{array}$ \\
\hline Smother & & $\begin{array}{l}.0071 \\
(1.40)\end{array}$ & & $\begin{array}{c}.0052 \\
(1.11)\end{array}$ \\
\hline Lang & & $\begin{array}{l}.2050 \\
(3.68)\end{array}$ & & $\begin{array}{l}.2212 \\
(4.33)\end{array}$ \\
\hline Exword & & $\begin{array}{l}.0912 \\
(1.64)\end{array}$ & & $\begin{array}{c}.0832 \\
(1.63)\end{array}$ \\
\hline Prom & & $\begin{array}{l}.3061 \\
(6.85)\end{array}$ & & $\begin{array}{c}.3254 \\
(7.85)\end{array}$ \\
\hline Child & & $\begin{array}{l}-.0360 \\
(-0.70)\end{array}$ & & $\begin{array}{c}-.0347 \\
(-0.74)\end{array}$ \\
\hline House & & $\begin{array}{l}.0728 \\
(1.70)\end{array}$ & & $\begin{array}{c}.0314 \\
(0.80)\end{array}$ \\
\hline Car & & $\begin{array}{l}.3715 \\
(7.70)\end{array}$ & & $\begin{array}{l}.4036 \\
(9.07)\end{array}$ \\
\hline Lived in Taguatinga 5 years ago & $\begin{array}{c}-.3937 \\
(-5.63)\end{array}$ & $\begin{array}{c}-.2619 \\
(-4.19)\end{array}$ & $\begin{array}{l}-.3676 \\
(-5.22)\end{array}$ & $\begin{array}{c}-.2354 \\
(-3.81)\end{array}$ \\
\hline Lived in Ceilândia 5 years ago & $\begin{array}{c}-.5341 \\
(-6.97)\end{array}$ & $\begin{array}{c}-.3133 \\
(-4.45)\end{array}$ & $\begin{array}{c}-.4843 \\
(-6.43)\end{array}$ & $\begin{array}{c}-.2705 \\
(-4.03)\end{array}$ \\
\hline Lived in Sobradinho 5 years ago & $\begin{array}{c}-.5513 \\
(-7.87)\end{array}$ & $\begin{array}{l}-.3830 \\
(-6.00)\end{array}$ & $\begin{array}{l}-.5219 \\
(-7.45)\end{array}$ & $\begin{array}{c}-.3533 \\
(-5.67)\end{array}$ \\
\hline Lived in Other Count 5 years ago & - & - & $\begin{array}{l}-.3287 \\
(-4.48)\end{array}$ & $\begin{array}{c}-.1442 \\
(-2.25)\end{array}$ \\
\hline Constant & $\begin{array}{l}.7901 \\
(4.98)\end{array}$ & $\begin{array}{l}.9451 \\
(6.51)\end{array}$ & $\begin{array}{l}.6806 \\
(4.59)\end{array}$ & $\begin{array}{l}.9171 \\
(6.87)\end{array}$ \\
\hline $\mathrm{R}^{2}$ Adj. & .6562 & .7411 & .6487 & .7411 \\
\hline Number of observations & 652 & 651 & 779 & 778 \\
\hline
\end{tabular}


According to Tables 3 and 5, there is little doubt that there is an actual wage differential caused by an individual's place of residence. To verify this result, the results gathered from 3 Stage Least Squares (3LS) are shown in Table 6. In this table, there are two dependent variables: Lwh and S. For Lwh, the use of the two previous sets of explanatory variables is continued. For S, following explanatory variables are used: Smother, man, white, married, Taguatinga, Ceilândia and Sobradinho. The novelty of this regression is that now there is an attempt to control the endogeneity of years of study. To save space, we will just report the results for the equation of the greatest interest, which is the wage equation. ${ }^{4}$

The results presented in Table 6 leave no doubt concerning the occurrence of a significant wage punishment for the residents of Taguatinga (37 percent), Ceilândia (51 percent) and Sobradinho (56 percent). The remaining results are similar to those shown in the previous regressions. After detecting the difference in wages, generated by the place of residence, it now remains for us to try to propose an explanation for this differential. As mentioned in the introduction of this article, there are at least 4 possible explanations for such a fact: 1) Spatial Mismatch Hypothesis (SMH); 2) economic rationale; 3) statistical discrimination; and 4) preference discrimination.

According to the Spatial Mismatch Hypothesis (SMH) some groups of individuals (due to their race, ethnic background, creed, etc.) are not allowed to rent houses in city suburbs where the best job opportunities can be found. As a result, these individuals must live in counties far from better job opportunities and consequently are not able to compete for the best jobs and higher wages. For example, Blacks could possibly have difficulty renting or buying residences in certain neighborhoods where the majority of residents are white. Therefore, they would be forced to live in other areas. If the better job opportunities are in white neighborhoods, there may be a greater distance between where Blacks actually live and where the best jobs are actually located. Such a situation makes it difficult for Blacks to get better employment, resulting in: a) different wages for blacks and whites; and b) different wages caused by the place of residence.

According to the above paragraph, SMH provides an explanation for the wage differential resulting from the places of residence. However, $\mathrm{SMH}$ is fundamentally based upon the fact that discrimination against some groups of individuals exists in the real estate market. Perhaps this is a reasonable hypothesis for some counties in the United States. But it definitely does not apply to the real estate market in the Distrito Federal State. A brief glance at the data in Table 2 verifies this conclusion. Note that in the sampling, 73\% of those interviewed in Brasília were white. In Taguatinga that percentage was 72\%, in Ceilândia, it was 32\% and in Sobradinho, the percentage of whites was $65 \%$. Percentage-wise, it is apparent that the white population in Taguatinga is almost the same as in Brasília. Furthermore, Sobradinho (the county which has the greatest magnitude of discrimination) possesses a white population very similar to that of Brasília and double that of Ceilândia. To accept the SMH we must not recognize a wage differential between the Brasília and Taguatinga counties and, additionally, the wage differential

4 Evidently, the complete set of results can be obtained from the authors upon request. 
must be much more severe in Ceilândia than in Sobradinho. These facts are not in accordance with the results found in this study.

Table 6 - Estimative by $3 \mathrm{LS}^{*}$

\begin{tabular}{|c|c|c|}
\hline Dependent Variable: Lwh & Restricted Set & Broad Set \\
\hline$S$ & $\begin{array}{l}.1850 \\
(7.42)\end{array}$ & $\begin{array}{l}.0848 \\
(1.85)\end{array}$ \\
\hline Experience & $\begin{array}{l}.0441 \\
(4.93)\end{array}$ & $\begin{array}{l}.0446 \\
(5.64)\end{array}$ \\
\hline Experience ${ }^{\wedge}$ & $\begin{array}{c}-.0005 \\
(-2.96)\end{array}$ & $\begin{array}{l}-.0006 \\
(-3.80)\end{array}$ \\
\hline Formal & $\begin{array}{l}.1027 \\
(1.56)\end{array}$ & $\begin{array}{l}.0741 \\
(1.31)\end{array}$ \\
\hline Union & $\begin{array}{l}.0243 \\
(0.48)\end{array}$ & $\begin{array}{l}-.0201 \\
(-0.45)\end{array}$ \\
\hline Man & $\begin{array}{l}.2049 \\
(4.76)\end{array}$ & $\begin{array}{l}.1250 \\
(3.32)\end{array}$ \\
\hline White & $\begin{array}{l}.0668 \\
(1.51)\end{array}$ & $\begin{array}{l}-.0148 \\
(-0.38)\end{array}$ \\
\hline Married & $\begin{array}{l}.1914 \\
(3.60)\end{array}$ & $\begin{array}{l}.1460 \\
(3.01)\end{array}$ \\
\hline Spriv & & $\begin{array}{l}.0243 \\
(3.14)\end{array}$ \\
\hline Smother & & Instrument in the $S$ equation \\
\hline Lang & & $\begin{array}{l}.1942 \\
(3.35)\end{array}$ \\
\hline Exword & & $\begin{array}{l}.1157 \\
(1.16)\end{array}$ \\
\hline Prom & & $\begin{array}{l}.3178 \\
(5.36)\end{array}$ \\
\hline Child & & $\begin{array}{l}-.0130 \\
(-0.29)\end{array}$ \\
\hline House & & $\begin{array}{l}.0822 \\
(1.63)\end{array}$ \\
\hline Car & & $\begin{array}{l}.3834 \\
(6.15)\end{array}$ \\
\hline Taguatinga & $\begin{array}{l}-.3771 \\
(-3.41)\end{array}$ & $\begin{array}{c}-.3694 \\
(-3.53)\end{array}$ \\
\hline Ceilândia & $\begin{array}{c}-.5113 \\
(-3.35)\end{array}$ & $\begin{array}{c}-.5078 \\
(-3.58)\end{array}$ \\
\hline Sobradinho & $\begin{array}{c}-.5118 \\
(-3.73)\end{array}$ & $\begin{array}{c}-.5617 \\
(-4.16)\end{array}$ \\
\hline Constant & $\begin{array}{c}.4983 \\
(1.17)\end{array}$ & $\begin{array}{l}1.341 \\
(2.45)\end{array}$ \\
\hline $\mathrm{R}^{2}$ Adj. & .6690 & .7662 \\
\hline Number of observations & 779 & 778 \\
\hline
\end{tabular}

* the values in parentheses are the $\mathrm{t}$-values of the variables. 
An important detail worth mentioning is that in the great majority of cases, there are two options when renting houses in the Distrito Federal state. One option is to prove income and present 2 co-signers (people who will be held responsible for paying the rent if the renter does not). One of the co-signers must own property in the Distrito Federal state. The second option is to prove income and pay a down payment equivalent to 6 months rent (this money is returned at the end of the contract). In other words, there is not much room for discrimination if the individual fulfills one of the prerequisites cited above. However, in some instances, it may be argued that salespeople were unfair in regards to certain groups of people. Nevertheless, in the Distrito Federal state, a great part of the real estate is announced in newspapers and websites that include photos. This reduces the dependence that an individual may feel toward the real estate agent. Furthermore, to rent property the salesman almost never accompanies the real estate clients. The practice is that the client chooses the property they want to visit and picks up the keys at the agency (leaving some I.D at the real estate company). The client then inspects the selected property alone, without the presence of the real estate broker. Thus, the possibility of discrimination occurring in the real estate market in the Distrito Federal is quite remote, which eliminates the SMH as a possible explanation for the wage differential amongst the counties in the Distrito Federal.

It is necessary to verify the economic rationale behind the existence of the wage differential amongst the Distrito Federal counts. One possibility is that people who live in Taguatinga, Ceilândia and Sobradinho spend more time commuting to their workplaces. Because of travel time, they arrive at their jobs feeling more tired and their productivity is reduced. In support of this hypothesis, Table 7 presents data about the time an individual takes to reach his job and his means of transportation. Note that people residing in Brasília use their cars more often when traveling to their workplace, which results in less time spent in transit to their jobs. In addition, almost $90 \%$ of the residents of Brasília spend less than 20 minutes in transit to their jobs, and just $2.7 \%$ spend more than 40 minutes in travel time. Therefore, the wage differential, based on productivity, between Brasília and the other counties, could be logically compared and analyzed. According to Table 7, individuals living outside Brasília spend more time in the traveling to their jobs, use less comfortable transports (the majority of them have to rely on public transportation, which in the Distrito Federal State, lacks quality) and almost half of them spend more than 40 minutes in transit to their workplace. 
Table 7 - Time spent to arrive at workplaces and means of transportation

\begin{tabular}{lcccc}
\hline Variable & Brasília & Taguatinga & Ceilândia & Sobradinho \\
\hline Time spent to workplace (in minutes) & 14.92 & 36.57 & 37.17 & 34.81 \\
Standard Deviation (in minutes) & 8.25 & 20.89 & 23.97 & 16.57 \\
Lower and Upper time spent (in minutes) & $2-50$ & $3-100$ & $1-120$ & $5-100$ \\
\% that spent more than 40 minutes & $2.7 \%$ & $44.9 \%$ & $47.9 \%$ & $50.5 \%$ \\
\% that spent less than 20 minutes & $87.9 \%$ & $29.4 \%$ & $34.9 \%$ & $28.1 \%$ \\
Percentage traveling by car & $68.1 \%$ & $36.1 \%$ & $22.1 \%$ & $26.8 \%$ \\
Percentage traveling by bus & $11.3 \%$ & $46.8 \%$ & $61.3 \%$ & $59.5 \%$ \\
\hline
\end{tabular}

As indicated above, the economics rationale based on commuting costs can explain a share of the wage differential between Brasília and the other counties. However, the explanation cannot be used to explain why there is such a great difference between the counts. As shown in Table 7, it is difficult to understand why residents from Sobradinho are less privileged than those living in Taguatinga. After all, these counties have similar statistics regarding the means of transport to work and time spent traveling to the workplace. According to data shown in Table 7, one would expect the greatest wage differential to be found in Ceilândia since the residents of this county spend more time getting to their workplaces and use private transportation less often. In addition, it is unusual that a difference of twenty minutes in the amount of time needed to travel to work would drive the wage differential to the high level reported in Tables 3,5 and 6 .

Discrimination occurring by preference is a possibility that must be examined. For example, the occurrence of discrimination by preference against Blacks is a common assumption in economic studies since: a) employers do not like Blacks (discrimination by preference of the employer); or b) clients do not like to be assisted by Blacks (discrimination by preference of the client).

In the dataset presented, there is a dummy variable that assumes a value equal to 1 (one) if an individual lives in the count where he works and 0 (zero) otherwise. Table 8 shows the percentage of individuals who live in the same county in which they work. This table verifies that 81.6 percent of the residents of Brasília work in Brasília. This percentage shrinks to 31.3 percent for Taguatinga, 40.8 percent for Ceilândia and 38.1 percent for Sobradinho. 
Table 8 - Percentage of individuals who live and work in the same count

\begin{tabular}{lc}
\hline Administrative Count & Percentage of individuals who live and work in this count \\
\hline Brasilia & $81.62 \%$ \\
Taguatinga & $31.38 \%$ \\
Ceilândia & $40.86 \%$ \\
Sobradinho & $38.18 \%$ \\
\hline
\end{tabular}

It makes no sense that blacks will discriminate (by taste or preference) against blacks, or that women will discriminate against women. In the same way, there is no sense in a company located in Taguatinga discriminates against the residents from Taguatinga. Similarly, why would clients who buy products in Taguatinga to discriminate against residents from this county? If a client chooses to travel to Taguatinga (or Ceilândia or Sobradinho) to buy a product, discrimination against the dwellers of that county makes no sense. After all, if he is willing to travel to that place, he should also is willing to be attended by a resident from that same area. Thus, the greater the percentage of individuals who work and live in the same county, the less discrimination by preference against the residents of that area should be.

Data in Table 8 indicated that $40 \%$ of Ceilândia residents also work there. So it seems to be illogical that such people suffer wage discrimination by preference. A similar analysis can be made of Taguatinga and Sobradinho. Observe that, of the 3 counties, Taguatinga is the city showing the smallest percentage of workers living in the same county. Thus it would be logical to expect greatest degree of discrimination by preference against the residents of Taguatinga. The estimates do not support this assumption. It appears that the existence of discrimination by preference is not the most adequate type of discrimination that represents the results.

Finally, one can suggest that the results encountered are due to the occurrence of statistical discrimination. That is, since employers are not completely familiar with the profile of each worker, they attribute to the worker the average characteristics of the group that the worker belongs. Thus, workers living in Brasília would be classified according to the average residents of Brasila, and the same would apply regarding the residents of Taguatinga, Ceilândia and Sobradinho. Therefore, since Brasília is the richest county and has a population boasting the highest level of education, statistical discrimination against the residents of Taguatinga, Ceilândia and Sobradinho in favor of the residents of Brasília is a strong possibility.

In order to verify the hypothesis of statistical discrimination, the following procedure needs to take place. The mincerian equation should be re-estimated with the broad set of variables by OLS, ${ }^{5}$ however, just a sub-sample of the original dataset should be used. In our estimates, only those individuals who work and live in different counties will be included. The rationale for this is that now an employer must contract individuals from different counties. In doing so, he may apply his opinion regarding their group (city of residence) to these individuals. The

5 The estimate by two-stage least squares generates similar results. Such results can be obtained from the authors. 
occurrence of discrimination, then, implies statistical discrimination. In the second column of Table 9, our original sampling is used; however, a dummy variable (trregion) that assumes a value of 1 (one) if the individual lives and works in the same count and 0 (zero) otherwise is included. The idea is to verify if this variable is able to change the results found. In other words, the use of the variable will verify the validity of our results. Table 9 presents the results of these procedures.

According to individuals who live in Taguatinga and work outside Taguatinga earn wages that are approximately 19 percent less than the residents of Brasília who work outside Brasília. For Ceilândia and Sobradinho these results are 26 percent and 27 percent, respectively. These percentages indicate the existence of statistical discrimination against the residents of Taguatinga, Ceilândia and Sobradinho. These results imply that residents of Brasília working in other counties, even after the control by a series of variables, receive higher wages than residents of Taguatinga (or Ceilândia or Sobradinho) working in other counties. Therefore, a resident of Braslia working in Taguatinga receives higher wages than a resident of Taguatinga working in Brasília (even after the control by a wide range of variables). Another important finding is that the inclusion of the dummy variable trregion does not qualitatively alter the results. Note that trregion is positive and statistically significant at a $10 \%$ level. This indicates that individuals that live and work in the same count receive a higher wage than individuals that work outside their county of residence. This result can be interpreted as both:

- evidence that the productivity model makes sense. That is, the fact that the individual lives and works in the same place would save travel time and energy of the worker making him more productive and, consequently, able to receive a higher wage; or

- evidence in favor of the statistical discrimination model. That is, when the employer has to hire someone from other counties (which he has less information about) he applies to the new worker the group characteristics. 
Table 9 - Mincerian regression for people who work and live in different counts*

\begin{tabular}{|c|c|c|}
\hline Dependent Variable: Lwh & OLS (1) & OLS (2) \\
\hline$S$ & $\begin{array}{l}.0905 \\
(9.63)\end{array}$ & $\begin{array}{c}.0884 \\
(12.61)\end{array}$ \\
\hline Experience & $\begin{array}{l}.0483 \\
(4.61)\end{array}$ & $\begin{array}{l}.0454 \\
(6.02)\end{array}$ \\
\hline Experience ${ }^{\wedge}$ & $\begin{array}{l}-.0007 \\
(-3.42)\end{array}$ & $\begin{array}{c}-.0006 \\
(-3.90)\end{array}$ \\
\hline Formal & $\begin{array}{l}.0445 \\
(0.59)\end{array}$ & $\begin{array}{l}.0763 \\
(1.34)\end{array}$ \\
\hline Union & $\begin{array}{l}.0554 \\
(1.02)\end{array}$ & $\begin{array}{c}-.0290 \\
(-0.73)\end{array}$ \\
\hline Man & $\begin{array}{l}.0878 \\
(1.82)\end{array}$ & $\begin{array}{l}.1271 \\
(3.48)\end{array}$ \\
\hline White & $\begin{array}{l}-.0413 \\
(-0.82)\end{array}$ & $\begin{array}{c}-.0095 \\
(-0.25)\end{array}$ \\
\hline Married & $\begin{array}{l}.1076 \\
(1.97)\end{array}$ & $\begin{array}{c}.1504 \\
(3.56)\end{array}$ \\
\hline Spriv & $\begin{array}{l}.0314 \\
(4.38)\end{array}$ & $\begin{array}{l}.0218 \\
(4.70)\end{array}$ \\
\hline Smother & $\begin{array}{l}.0056 \\
(0.86)\end{array}$ & $\begin{array}{l}.0022 \\
(0.49)\end{array}$ \\
\hline Lang & $\begin{array}{l}.1655 \\
(2.39)\end{array}$ & $\begin{array}{l}.1894 \\
(3.87)\end{array}$ \\
\hline Exword & $\begin{array}{l}.0020 \\
(0.03)\end{array}$ & $\begin{array}{l}.0821 \\
(1.68)\end{array}$ \\
\hline Prom & $\begin{array}{l}.3177 \\
(6.04)\end{array}$ & $\begin{array}{l}.3004 \\
(7.55)\end{array}$ \\
\hline Child & $\begin{array}{l}.0125 \\
(0.21)\end{array}$ & $\begin{array}{c}-.0228 \\
(-0.50)\end{array}$ \\
\hline House & $\begin{array}{l}.1542 \\
(3.05)\end{array}$ & $\begin{array}{c}.0718 \\
(1.90)\end{array}$ \\
\hline Car & $\begin{array}{l}.3425 \\
(6.04)\end{array}$ & $\begin{array}{l}.3655 \\
(8.53)\end{array}$ \\
\hline Trregiao & - & $\begin{array}{l}.0623 \\
(1.68)\end{array}$ \\
\hline Taguatinga & $\begin{array}{c}-.1952 \\
(-2.09)\end{array}$ & $\begin{array}{l}-.3517 \\
(-5.99)\end{array}$ \\
\hline Ceilândia & $\begin{array}{l}-.2683 \\
(-2.64)\end{array}$ & $\begin{array}{c}-.5020 \\
(-7.47)\end{array}$ \\
\hline Sobradinho & $\begin{array}{c}-.2743 \\
(-2.81)\end{array}$ & $\begin{array}{l}-.5607 \\
(-9.08)\end{array}$ \\
\hline Constant & $\begin{array}{l}1.055 \\
(5.28)\end{array}$ & $\begin{array}{l}1.277 \\
(9.13)\end{array}$ \\
\hline $\mathrm{R}^{2} \mathrm{Adj}$. & .7115 & .7619 \\
\hline Number of observations & 409 & 778 \\
\hline
\end{tabular}

* the values in parentheses are the $\mathrm{t}$-values of the variables. 


\section{Conclusions}

This article used an original dataset that provided information for 4 administrative counties in the state of the Distrito Federal in Brazil. Armed with these data a series of econometric procedures were carried out to verify the existence of wage differences resulting from the place of residence of the worker. The econometric results demonstrated to be extremely robust to a wide set of statistical procedures. In addition, all results supported the existence of severe wage punishment against workers that lived in poor areas.

It may be argued that our results are biased since the decision regarding the place of residence is endogenous. Individuals with more skills will possibly migrate to rich areas, and low skilled workers will live in poor areas. Such choices of residence will bias the results in favor of wage differences between areas. To prevent this bias we performed two different econometric procedures. First, we estimated the regressions using two-stage least squares (2-LS). Secondly, we used a proxy that highly correlated with the place of the residence, but was not associated with the actual wage received by the workers. This proxy kept our results qualitatively the same. In other words, our statistical procedure addressed the endogeneity problem.

After finding a statistically significant wage gap between workers from different counties, we proposed four different explanations for this gap. While we did not find strong evidence in favor of both the Spatial Mismatch Hypothesis (SMH) and the discrimination by preference, we did not rule out the explanations based on economic rationale (commuting cost) and statistical discrimination.

Although it was showed that part of the wage differential between counties was attributed to factors linked to worker productivity, such as time spent commuting from home to workplace, it was apparent that an important part of this differential was linked to the existence of statistical discrimination against those living in poor counties.

\section{REFERENCES}

BARBOSA FILHO, F.; PESSÔA, S. Retorno da educação no Brasil. Pesquisa e Planejamento Econômico, 2008. No prelo.

BECKER, G. The economics of discrimination. The University of Chicago Press, 1957.

BECKER, G. Human capital. Columbia University Press, 1975.

BIDDLE, J. I.; Hamermesh, D. Beauty, productivity and discrimination: lawyers' looks and lucre. Journal of Labor Eonomics, 16, p. 172-201, 1998.

BOARDMAN, J.; FIELD, S. H. Spatial mismatch and racial differences in male joblessness: Cleveland and Milwaukee, 1990. Sociological Quarterly, v. 43, p. 237-55, 2002.

CAIN, G. The economic analysis of labor market discrimination: a survey. In Ashenfelter, Orley; Layard, Richard (ed.). Handbook of labor economics. Amsterdam: North Holand, 1986. p. 693-785. 
CARD, D. Estimating the return to schooling: progress on some persistent econometric problems. Econometrica, v. 69, n. 5, p. 1127-1160, 2001.

FARMULARI, M. The Effects of a Disability on Labor Market Performance: The Case of Epilepsy. Southern Economic Journal, p. 1072-1087, 1992.

GABRIEL, S.; ROSENTHAL, S. Commutes, Neighborhoods Effects and Earnings: An Analysis of Racial Discrimination and Compensating Differentials. Journal of Urban Economics, v. 40, 1996, p. 61-83.

GAREN, J. The Returns to Schooling: A Selectivity Bias Approach with a Continuous Choice Variable. Econometrica, v. 52, n. 5, p. 1199-1218, 1984.

GOBILLON, L.; SELOD, H.; ZENOU, Y. Spatial mismatch: from the hypothesis to the theories. London, 2003. (CEPR Discussion Paper, n. 3740)

GREKING, S. D.; WEIRICK, W. N. Compensating differences and interegional wage differentials. Review of Economics and Statistics, p. 483-487, 1983.

GRILICHES, Z. Estimating the returns to schooling: some econometrics problems. Econometrica, v. 45, n. 1, p. 1-22, 1977.

GYOURKO, J.; TRACY, J. The importance of local fiscal conditions in analyzing local labor markets. Journal of Political Economy, p. 1208-1231, 1989.

HAMERMESH, D. S.; BIDDLE, J. E. Beauty and the labor market. American Economic Review, v. 84, p. 1174-1194, 1994.

KAIN, J. F. Housing segregation, negro employment, and metropolitan decentralization. Quarterly Journal of Economics, v. 82, p. 175-83, 1968.

. The cumulative impacts of slavery: jim crow, and housing market discrimination on black welfare. October, 1992. (HEIR Discussion Paper, n. 1608).

KATZ, L. F. Efficiency wages theories: a partial evaluation. NBER, p. 235-276, 1986.

MINCER, J. Schooling, experience and earnings. National Bureau of Economic Research, 1974.

MOURA, R. L. Testando as hipóteses do modelo de Mincer para o Brasil. Revista Brasileira de Economia, 2008. No prelo.

PERSICO, N.; POSTLEWAITE, A. The effect of adolescent experience on labor market outcomes: the case of height. Journal of Political Economy, v. 112, n. 5, p. 1019-1053, 2004.

PHELPS, E. S. The statistical theory of racism and sexism. American Economic Review, LXII, p. 659661, 1972,

RESENDE, M.; WYLLIE, R. Retornos para educação no Brasil: evidências empíricas adicionais. Economia Aplicada, v. 10, n. 3, p. 349-365, 2006.

SACHSIDA, A., LOUREIRO, P. R. A.; MENDONÇA, M. J. C. Um estudo sobre retorno em escolaridade no Brasil. Revista Brasileira de Economia, v. 58, n. 2, 2004.

SHAPIRO, C.; STIGLITZ, J. Equilibrium unemployment as a worker discipline device. American Economic Review, 74, p. 433-444, 1984.

SPENCE, M. Job market signaling. Quarterly Journal of Economics, p. 355-374, 1973. 